\title{
THE IMPLEMENTATION OF THE EXPRESSIONIST ARCHITECTURE IN FLOWER Park Design Strategy in Surakarta
}

\author{
Penerapan Nilai Arsitektur Ekspresionis Dalam Strategi \\ Perancangan Taman Bunga Di Surakarta
}

\author{
Alfinda Krista Rahardyana ${ }^{1 *}$, Maya Andria Nirawati ${ }^{2}$, Ana Hardiana ${ }^{3}$ \\ Program Studi Arsitektur, Fakultas Teknik, Universitas Sebelas Maret ${ }^{1}$ \\ alfindakr@gmail.com ${ }^{*}$ \\ Program Studi Arsitektur, Fakultas Teknik, Universitas Sebelas Maret ${ }^{2}$ \\ Program Studi Arsitektur, Fakultas Teknik, Universitas Sebelas Maret3
}

\begin{abstract}
Park is a tourism place that shows the beauty of nature, including flower. Based on LIPI's data Indonesia has 6.000 kind of flowers. But, there are 126 plants at least with the highest threat of extinction, including flowers (IUCN Red List).As one of tourist destination, Indonesia has many tourism city, including Surakarta that considered insufficient in accomodate park, with only has 4 parks. This is correlate with the availability of The Green Open Space at Surakarta (9,7\% from 20\%). Flower park needs to be made that can increase the amount ofThe Green Open Space in Surakarta. It will be place for recreation, conservation, ecology, education and economy.

The method used is descriptive qualitative with case study through stages of expressionist architecture literature, data observation, precedent study, physical condition of site and government regulation. The conclusion of this analysis is obtained the suitable application with expressionist architecture value in the design, that is application in space (compound building according to function), site (access, climate, view and orientation, noise and pollution, zoning), shape and mass (combination and curve aplication), Appearance (uniformal-abstract phylosophy, material exposure, imaginativeillusive, emotional psychological) and building structure (constructive material).
\end{abstract}

Keywords: Flower Park, Expressionist Architecture

\section{PENDAHULUAN}

Wisata taman adalah wisata yang diciptakan untuk mengakomodasi kebutuhan rekreasi yang berkaitan dengan keindahan alam, terutama flora dan fauna.

Flora Indonesia termasuk dalam kategori flora Malesiana yang diperkirakan memiliki sekitar 25\% dari spesies tumbuhan berbunga yang ada di dunia yaitu sekitar 20.000 spesies, $40 \%$-nya merupakan tumbuhan asli Indonesia, yang mana baru terdapat 8.000 jenis yang sudah diidentifikasi, yang mana jumlah ini hanya $20 \%$ dari total jumlah flora yang diperkirakan ada di Indonesia. Data IUCN Red List menunjukkan bahwa ada 6 status kepunahan di Indonesia yaitu Least Concern (681 spesies), Near Threatened (108 spesies), Vulnerable (227 spesies), Endangered (94 spesies), Critically Endangered (117 spesies), dan Extinct in The Wild (1 spesies).

Menurut Peraturan Pemerintah Republik Indonesia Nomor 7 Tahun 1999 Tentang Pengawetan Jenis Tumbuhan dan Satwa, jenis tanaman bunga yang termasuk dalam tanaman yang dilindungi hanya sejumlah 58 spesies. Hal ini membuat konservasi tanaman, termasuk tanaman bunga sangat penting untuk dilakukan dan diusahakan demi menjaga keberlangsungan tanaman tersebut di Indonesia. 
Sebagai tempat wisata, Taman Bunga harus dirancang di lokasi yang berpotensi pariwisata. Data wisatawan Surakarta wisatawan pada wisata taman yaitu mancanegara tahun 20102015 sejumlah 6.166 orang dandomestiktahun 2010-2015 pada wisata taman sejumlah 9.275.540 orang.Hal ini menandakan bahwa kota Surakarta memiliki potensi untuk pengembangan objek wisata, terkhusus wisata taman.

Ketersediaan wisata taman/ alam pun masih sangat sedikit, hanya 4 buah yakni Taman Satwataru Jurug, Taman Balekambang, Taman Sriwedari dan Taman Banjarsari. Kurangnya keberadaan wisata taman di Surakarta ini juga berhubungan dengan isu lokal yaitu kurangnya Ruang Terbuka Hijau yang baru terealisasi $9,7 \%$. Jumlah tersebut belum sesuai target $20 \%$ berdasarkan Undang Undang (UU) Nomor 32 Tahun 2009 tentang Pengelolaan dan Perlindungan Lingkungan Hidup.

Isuini dapat ditanggapi denganmelakukan perancangan sebuah objek wisata taman di Surakarta yang juga memenuhi kebutuhan konservasi tanaman bunga, serta fungsi pendukung lain yaitu fungsi edukasi dan wisata tanaman bunga, mengingat belum adanya wisata sejenis yang ada di kota Surakarta.

Taman bunga sendiri adalah area yang ditanami berbagai macam tumbuhan bunga dan menggunakan beberapa ornamen tambahan yang rekreatif. Taman bunga memiliki beberapa prinsip desain, seperti tema, gradasi, kontras, dan keseimbangan yang harus dipenuhi dalam desainnya.

Bunga-bunga yang bisa digunakan antara lain bunga-bunga yang tahan panas seperti anggrek karawai, anggrek larat, anggrek vanda, dan lainlain, yang juga termasuk bunga yang dilindungi oleh pemerintah. Jenis lain yang mungkin ditanam pada taman bunga ini adalah bunga rambat yang juga dijadikan vertical garden, Taman bunga ini akan didesain menjadi area indoor dan area outdoor. Area indoor akan menggunakan bentuk kubah yang tinggi dengan material kaca sehingga area taman indoorsehingga memenuhi kebutuhan cahaya matahari dan sirkulasi udara. Sedangkan area outdoor akan dilengkapi dengan penyiram air otomatis untuk mengontrol kebutuhan air pada tanaman bunga.
Oleh karena itu, penerapan Arsitektur Ekspresionis dipilih sebagai pendekatan arsitektural dalam proses perencanaan dan perancangan Taman Bunga di Surakarta.Pengaplikasian nilai dan pedoman arsitektur ekspresionis berguna untuk menciptakan desain bangunan menjadi bangunan yang harmonis dengan alam serta tidak monoton dengan penggunaan bentukbentuk lengkung yang menggambarkan keindahan taman bunga. Hal ini juga berguna untuk menarik pengunjung datang serta dapat menjadi ikon baru Surakarta karena bangunan yang menggunakan banyak ornamen lengkung sendiri belum terlalu banyak ada di Surakarta.

\subsection{Arsitektur Ekspresionis}

Arsitektur Ekspresionis menjunjung tinggi kebebasan dari arsitek/perancang dalam mengekspresikan emosi dan perasaannya. Kata ekspresi adalah suatu ungkapan gaya dari seseorang (Sp, 2000). Gaya yang dimaksud adalah kekuatan antara seni dan juga teknik. Dalam hal ini kemudian muncul suatu pengekspresian emosi lewat bentuk bangunan.

Emosi dan perasaan ini kemudian dituangkan dalam sebuah desain bangunan yang dapat dirasakan dan dipahami oleh orang lain dengan tepat. Kebebasan ini juga diwujudkan lewat membebaskan arsitek dari aturan desain konvensional, seperti aturan modul bangunan, aturan geometri, dan lain sebagainya, yang membuat hasil akhir desain bangunan tidak terlihat monoton dan kaku dengan bentukbentuk yang geometris, dan juga desain dapat menggambarkan makna yang kaya akan emosi dan rasa dari arsitek.Arsitektur ekspresionis berusaha menggebrak dan melepaskan diri dari konsep-konsep statis kuno demi dinamisme yang modern (Van de Ven, 1991). Terdapat beberapa nilai arstektur ekspresionis yang akan diterapkan dalam perencanaan dan perancangan ini, yaitu:

\section{a. Menghargai Kebebasan Bentuk dan Garis}

Arsitek diberi kebebasan dalam mengolah bentuk maupun fasad bangunannya dengan tidak harus terpaku pada bentuk ataupun garisgaris khusus sehingga arsitek bebas untuk membentuk bangunan bersudut, lengkung, dan lain sebagainya sehingga dapat dihasilkan bangunan yang tidak bersifat kaku. 
b. Menghasilkan Bentuk Bangunan yang Tidak Monoton

Arsitektur ekspresionis menghargai kebebasan dalam mengeksplorasi bentuk dan garis pada bangunan. Hal ini tentunya membuat hasil akhir dari desain bangunan memiliki wujud yang unik, ekspresif dan berbeda.

c. Mampu Mengekspresikan Bahasa Emosi dalam Bentuk dan Warna

Perwujudan emosi dan rasa ini dapat dilakukan dengan mengaplikasikan bentuk dan warna khusus yang mewakili emosi yang dirasakan oleh sang arsitek.

\section{d. Mampu Mengungkapkan Isi Hati}

Suatu pendekatan desain harus mampu menginterpretasikan emosi dan rasa dari sang arsitek yang ditampilkan lewat bentuk yang konkrit dan nyata (wujud bangunan).

\section{e. Melukiskan Emosi pada Orang Lain}

Arsitektur ekspresionis harus dapat mengekspresikan emosi dan rasa dari arsitek lewat bentuk, warna, serta komposisi bangunan.

f. Mengutamakan Olah Wujud daripada Olah Ruang

Arsitektur Ekspresionis yang pada dasarnya mengutamakan kemampuan dan kebebasan berekspresi dari sang arsitek, lebih mementingkan pengolahan wujud bangunan agar dapat menampilkan wujud bangunan yang unik dan tidak biasa serta tidak monoton.

\section{g. Menggunakan Material Khusus}

Arsitektur Ekspresionis memiliki pemilihan material khusus yang menjadi ciri khas tersendiri dari pendekatan ini. Material yang banyak digunakan dalam pendekatan arsitektur ekspresionis adalah baja, kaca, dan batu bata. Material-material ini dikategorikan dalam material konstruktif (Sudibyo, Purnomo \& Nugroho, 2016).

Ciri dari arsitektur ekspresionis yang digunakan dalam perencanaan dan perancangan ini adalah:

a. Menggunakan makna dari simbol dan ide ruang yang diterapkan dalam bangunan

b. Menggunakan bentuk yang terdiri dari material yang konstruktif berupa kaca, baja dan dinding beton/batu bata. c. Menggunakan kesamaan arti makna dari aliran Seni Ekspresionis.

d. Menggunakan kesamaan antara nilai Arsitektur Ekspresionis dengan objek bangunan.

Filosofi ekspresionis yang akan digunakan dalam perencanaan dan perancangan ini adalah:

a. Uniformal-Abstrak

Filosofi ini memiliki kriteria yaitu bentuk bebas-sederhana, bentuk hiperbolis-dinamis, menciptakan kesan tidak monoton dan pemberian kesan harmonis dengan lingkungan.

\section{b. Ekspos Material}

Filosofi ini memiliki kriteria yaitu Menunjukkan material yang digunakan pada bangunan dalam bagian tertentu serta lokalitas dan sederhana.

c. Imajinatif-Ilusif

Filosofi ini memiliki kriteria yaitu pemberian makna yang berbeda terhadap pengguna, bentuk yang komunikatif (kreatif dan variatif) serta menimbulkan kesan yang dapat dilihat dan dirasa oleh pengunjung.

\section{d. Identitas}

Filosofi ini memiliki kriteria yaitu memperlihatkan secara langsung fungsi bangunan (lewat tampilan) serta berkarakter.

\section{e. Psikologis-Emosi}

Filosofi ini memiliki kriteria yaitu dapat membentuk suasana serta menciptakan kesan yang dapat memberi pengaruh terhadap kegiatan di dalamnya.

\section{METODE}

Metode perancangan Taman Bunga dengan deskriptif kualitatif, dengan mentransformasikan konsep yang direncanakan menjadi desain yang dirancang (Fardaniwuri, Suparno \& Yuliarso, 2016). Desain dirancang dengan pendekatan Arsitektur Ekspresionisme yang diaplikasikan pada pengolahan ruang, tapak, bentuk dan massa, tampilan serta struktur bangunan.

a. Pengolahan Ruang 
Pengolahan ruang akan menerapkan ciri dari arsitektur ekspresionis yaitu penggunaan makna dari simbol dan ide ruang serta filosofi psikologis-emosi. Penerapan ini akan diwujudkan lewat pemberian tema yang berbeda pada setiap ruangnya dengan disesuaikan dengan fungsi ruangnya. Hal ini agar ruang dapat membentuk suasana serta menciptakan kesan yang dapat memberi pengaruh terhadap kegiatan di dalamnya.

Ruang kemudian akan dikelompokkan sesuai dengan fungsinya masing-masing sehingga akan didapatkan bangunan yang bersifat majemuk, untuk memudahkan alur kegiatan. Kualitas ruang akan ditentukan lewat aktivitas pengguna, kenyamanan pengguna, kebutuhan ruang, dan kriteria ruang dan zona ruang.

\section{b. Pengolahan Tapak}

Pengolahan tapak akan dibagi menjadi beberapa aspek, yaitu:

\section{1) Pengolahan Pencapaian}

Nilai arsitektur ekpresionis yang digunakan adalah kebebasan bentuk dan garis, mengungkapkan emosi lewat bentuk dan warna dan penyampaikan emosi/rasa dari perancang ke pengguna.

Penerapan nilai arsitektur ekspresionis ada pada pembuatan entrance yang dibuat jelas, efisien serta disesuaikan dengan keadaan lingkungan untuk memudahkan pengguna. Selain itu, entrance juga akan dibuat dinamis dengan mengeksplorasi bentuk dan garis dengan pengolahan bentuk jalur sirkulasi kendaraan serta pemberian beberapa elemen pendukung seperti tanaman dan kolam di sekitar jalur sehingga tidak monoton dan dapat mengekspresikan rasa tenang yang diharapkan mucul pada pengunjung ketika memasuki Taman Bunga.

\section{2) Pengolahan Iklim}

Nilaiarsitektur ekspresionis diterapkan lewatpenggunaan material konstruktif dan mengutamakan olah wujud.

Penerapan nilai arsitektur ekspresionis ada pada pembentukan bangunan yang bersifat majemuk (mengutamakan olah wujud) sesuai dengan fungsinya, juga berguna untuk memaksimalkan penerimaan angin, memecah angin agar tidak terlalu kencang terkena bangunan, juga pemaksimalan penerimaan cahaya matahari.

Penggunaan material konstruktif ada pada penggunaan skylight dan bukaan untuk memaksimalkan cahaya alami, serta penggunaan kolam untuk menyerap sinar panas matahari.

Bangunan taman indoor dibuat terbuka dengan penggunaan kaca sehingga cahaya alami dan bisa maksimal bagi tanaman namun juga tidak terlalu terpapar. Bentuk bangunan yang ekspresif dan dinamis (meliuk, berbentuk dome) serta penggunaan material-material konstruktif akan membentuk bayangan yang akan difungsikan untuk menjadi peneduh bagi pengguna juga menimbulkan keindahan estetis.

\section{3) Pengolahan View dan Orientasi}

Nilai arsitektur ekspresionis yang digunakan adalah mengekspresikan emosi lewat bentuk dan warna, kebebasan bentuk dan garis serta menggunakan makna dari simbol ide ruang.

Penerapan arsitektur ekspresionis pada view bangunan adalah dengan penggunaan taman sebagai area terbuka yang lapang sehingga menciptakan suasana yang rekreatif dan view yang asri. Pemberian sculpture bunga, pembuatan elemen alami seperti bukit buatan dan kolam (kebebasan bentuk dan garis) untuk menambah view dan pemberian papan nama. View menuju site yang diharapkan bangunan taman-taman indoor yang sedikit terlihat, bangunan pasar dan penunjang dengan bentuk yang ekspresif lewat permainan material dan warna (mengekspresikan bentuk dan warna) sehingga menarik pengunjung.

\section{4) Pengolahan Kebisingan dan Polusi}

Nilai arsitektur ekspresionis yang digunakan adalah penggunaan material konstruktif.

Penerapan arsitektur ekspresionis pada kebisingan dan polusi adalah dengan penggunaan elemen-elemen material konstruktif seperti bata sehingga didapatkan bentuk bangunan yang masif dan nantinya dapat memecahkan kebisingan.

\section{5) Pengolahan Zonasi.}

Ciri arsitektur ekspresionis yang digunakan adalah menggunakan makna dari simbol ide ruang, yang mana ide ruang yang digunakan 
adalah ruang yang dikategorikan menurut fungsi dan aktivitasnya.

\section{c. Pengolahan Bentuk dan Massa}

Pengolahan bentuk dan massa bangunan akan menerapkan kombinasi dari bentuk dasar (persegi, lingkaran, segitiga) dan bentuk garis ekspresionis (lihat pada Tabel 1).

Tabel 1. Bentuk Garis Ekspresionis

\begin{tabular}{|l|l|l|}
\hline No. & \multicolumn{1}{|c|}{ Bentuk Garis } & \multicolumn{1}{c|}{$\begin{array}{c}\text { Contoh dalam } \\
\text { Bangunan }\end{array}$} \\
\hline 1. & $\begin{array}{l}\text { Karakter: Garis } \\
\text { panjang lengkung - } \\
\text { lengkung dan meliuk } \\
\text { meliuk (emosi yang } \\
\text { tenang) }\end{array}$ & $\begin{array}{l}\text { Bangunan berbentuk } \\
\text { lengkung pengabungan } \\
\text { dengan bangunan yang } \\
\text { lainnya yang bentuknya } \\
\text { serupa, saling } \\
\text { menyambung. }\end{array}$ \\
\hline 2. & $\begin{array}{l}\text { Karakter: Garis yang } \\
\text { tidak teratur, dinamis } \\
\text { dan mencerminkan } \\
\text { suatu kebebasan } \\
\text { tanpa aturan. }\end{array}$ & $\begin{array}{l}\text { Bangunan tidak teratur, } \\
\text { zig - zag, menyudut } \\
\text { tajam dan menumpuk. }\end{array}$ \\
\hline 3. & $\begin{array}{l}\text { Karakter: Garis yang } \\
\text { lurus dan teratur } \\
\text { tegas dan sederhana } \\
\text { ) }\end{array}$ & $\begin{array}{l}\text { Bangunan masa } \\
\text { menyatu, stabil dan } \\
\text { sederhana }\end{array}$ \\
\hline
\end{tabular}

\section{d. Pengolahan Tampilan Bangunan}

Pengolahan bentuk dan massa akan menerapkan filosofi dari arsitektur ekspresionis, yaitu:

\section{1) Uniformal- Abstrak}

Filosofi ini diterapkan pada eksterior dengan menggunakan bentuk yang dinamis. Penataan lansekap meliuk memberi kesan harmonis. Penerapan pada interior dengan Pemberian elemen rekreatif (kolam, pohon).

\section{2) Ekspos Material}

Filosofi ini diterapkan pada eksterior dengan pengeksposan material (mengekspos besi dan kaca). Penerapan pada interior dengan Penggunaan unsur alam sehingga menghasilkan kesan alami.
3) Imajinatif - Ilusif

Filosofi ini diterapkan pada eksterior dengan menggunakan bentuk yang kreatif sehingga menarik dan sesuai dengan fungsi. Penerapan pada interior disesuaikan dengan fungsi agar memberikan makna yang tepat.

4) Identitas

Filosofi ini diterapkan pada eksterior dengan penggunaan ornamen-ornamen yang dapat menunjukkan fungsi bangunan tersebut. Penerapan pada interior dengan memberikan pembeda pada setiap desain ruang, disesuaikan dengan fungsinya.

\section{5) Psikologis - Emosi}

Filosofi ini diterapkan pada eksterior dengan memadukan warna dan tekstur untuk dapat membentuk suasana. Penerapan pada interior dengan penggunaan tema-tema tertentu pada ruang-ruang.

\section{e. Pengolahan Struktur}

Pengolahan struktur dan utilitas akan menerapkan nilai-nilai dari arsitektur ekspresionis yaitu penggunaan material konstruktif yaitu bata, kaca dan baja. Penggunaan material ini bertujuan untuk dapat membentuk struktur yang kuat serta yang dapat mendukung keberlangsungan dan keberdayatahanan bangunan.

Metode yang digunakan bertujuan untuk mendapatkan desain bangunan yang dapat mewadahi kegiatan pada taman bunga. Arsitektur Ekspresionis ditransformasikan dalam desain melalui ekspresi dan karakteristik desain bangunan taman bunga.

Perancangan pada bangunan akan menampilkan penyampaian citra ekspresi bentuk yang ditunjukkan melalui penataan perancangan tampilan bangunan, bentuk, serta perancangan ruang melalui penciptaan atmosfer ruang yang ekspresif melalui warna, tekstur dan ornamen-ornamen ruang yang digunakan, sehingga bangunan dapat mencerminkan kegiatan di dalamnya.

\section{HASIL DAN PEMBAHASAN}

Analisa hasil dan pembahasan akan menghasilkan penerapan nilai, pedoman dan filosofi arsitektur ekspresionis di dalam desain 
bangunan Taman Bunga. Nilai, pedoman dan filosofi ini akan diterapkan dalam pengolahan ruang, tapak, bentuk dan massa, tampilan bangunan, serta struktur bangunan.

\subsection{Pengolahan Ruang}

Ruang akan dibagi menjadi beberapa kelompok ruang yang kemudian diolah menjadi bangunan majemuk sesuai fungsinya untuk memudahkan alur kegiatan. Hal ini merupakan penerapan dari nilai menggunakan makna dari simbol ide ruang. Setiap kelompok ruang akan diberikan tema sesuai dengan fungsi dan aktivitas yang diwadahi agar dapat dapat memberi pengaruh pada kegiatan di dalamnya (lihat pada Tabel 2).

Tabel 2.Kebutuhan dan Besaran Ruang

\begin{tabular}{|l|l|}
\hline \multicolumn{2}{|c|}{ TOTAL BESARAN RUANG } \\
\hline $\begin{array}{l}\text { Kelompok Ruang } \\
\text { Penerima }\end{array}$ & $\pm 5.184,45 \mathrm{~m}^{3}$ \\
\hline $\begin{array}{l}\text { Kelompok Ruang } \\
\text { Pengelola }\end{array}$ & $\pm 4.185 \mathrm{~m}^{3}$ \\
\hline Kelompok Ruang Utama & $\pm 54.742 .23 \mathrm{~m}^{3}$ \\
\hline $\begin{array}{l}\text { Kelompok Ruang } \\
\text { Penunjang }\end{array}$ & $\pm 9.701,4 \mathrm{~m}^{3}$ \\
\hline Kelompok Ruang Servis & $\pm 6.869,2 \mathrm{~m}^{3}$ \\
\hline TOTAL & $\pm 80.682,28 \mathrm{~m}^{3}$ \\
\hline
\end{tabular}

\subsection{Pengolahan Tapak}

Tapak terpilih berada di Jalan Kyai H. Masykur, Jebres, Surakarta (lihat pada Gambar 1).

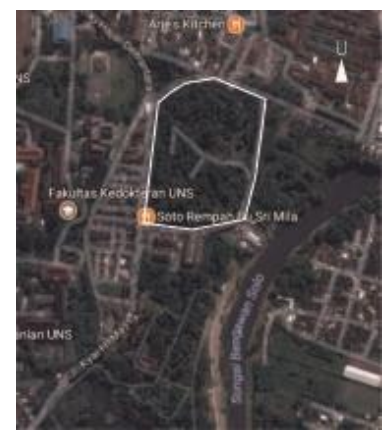

Gambar 1. Lokasi Tapak Taman Bunga Sumber: Google Maps

a. Pengolahan Pencapaian

Penerapan nilai arsitektur ekspresionis pada pencapaian yaitu kebebasan bentuk dan garis, mengungkapkan emosi lewat bentuk dan warna, serta penyampaikan emosi/rasa dari perancang ke pengguna (lihat pada Gambar 2).

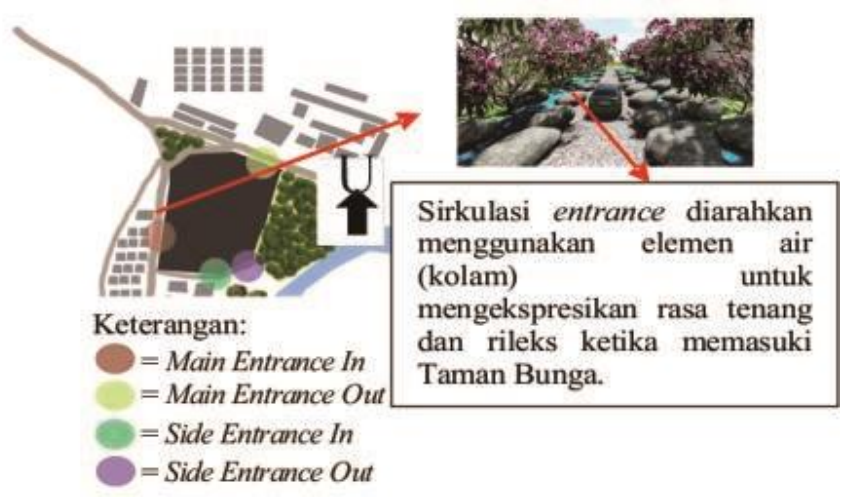

Gambar 2.Penerapan Arsitektur Ekspresionis pada Pencapaian

b. Pengolahan Iklim

Penerapan nilai arsitektur ekspresionis pada pengolahan iklim yaitu penggunaan material konstruktif dan mengutamakan olah wujud (lihat pada Gambar 3).

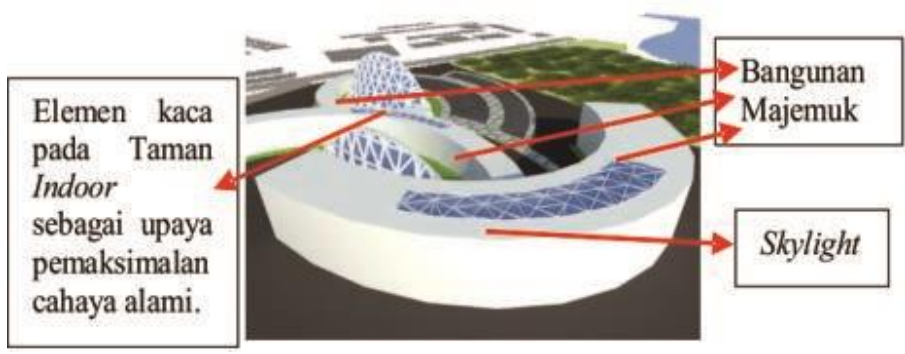

Gambar 3. Penerapan Arsitektur Ekspresionis pada Iklim

Bangunan akan bersifat majemuk sesuai dengan fungsinya, juga berguna untuk memaksimalkan penerimaan angin, pemecah angin, juga pemaksimalan penerimaan cahaya matahari.

Beberapa bangunan akan diberikan skylight dan bukaan untuk memaksimalkan cahaya alami, serta penggunaan kolam untuk menyerap sinar panas matahari.

Bangunan taman indoormenggunakan penutup kaca sehingga memaksimalkan cahaya alami bagi tanaman namun menjaga agar tidak terlalu terpapar. Bentuk bangunan yang ekspresif dan dinamis (meliuk, berbentuk dome) serta penggunaan material-material konstruktif akan membentuk bayangan yang akan difungsikan untuk menjadi peneduh bagi pengguna juga menimbulkan keindahan estetis.

c. Pengolahan View dan Orientasi

Penerapan nilai arsitektur ekspresionis yaitu mengekspresikan emosi lewat bentuk dan 
warna, kebebasan bentuk dan garis serta menggunakan makna dari simbol ide ruang (lihat pada Gambar 4).
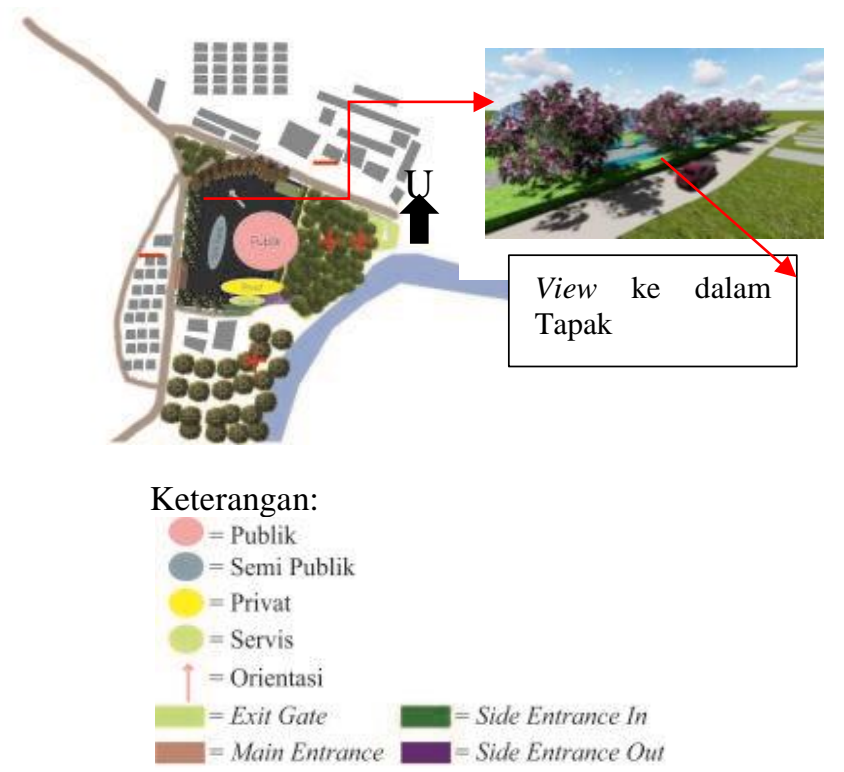

Gambar 4. Penerapan Arsitektur Ekspresionis pada View dan Orientasi

\section{d. Pengolahan Kebisingan dan Polusi}

Penerapan nilai arsitektur ekspresionis yaitu penggunaan material konstruktif (lihat pada Gambar 5).

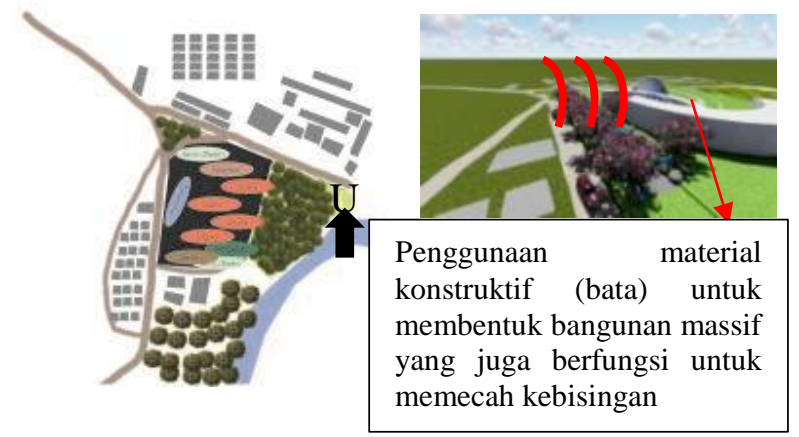

Gambar 5. Penerapan Arsitektur Ekspresionis padaKebisingan dan Polusi

\section{e. Pengolahan Zonasi}

Konsep zonasi pada site dengan menggunakan penerapan nilai arsitektur ekspresionis yaitu menggunakan makna dari simbol ide ruang, yang mana ide ruang yang digunakan adalah ruang yang dikategorikan menurut fungsi dan aktivitasnya (lihat pada Gambar 6).

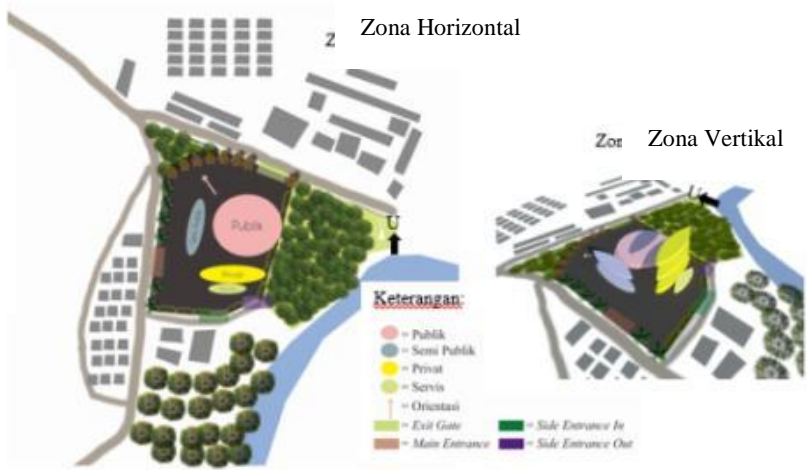

Gambar 6. Penerapan Arsitektur Ekspresionis pada Zonasi

\subsection{Pengolahan Bentuk dan Massa}

Pengolahan bentuk dan massa bangunan dengan penerapan arsitektur ekspresionis akan dirancang sebagai berikut:

a. Massa disusun majemuksesuai dengan fungsinya.

b. Massa menggunakan kombinasi lingkaran dan persegi sehingga tersusun bentuk yang dinamis, fungsional, stabil, namun tetap estetis dan rekreatif.

c. Massa menggunakan penerapan bentuk garis meliuk (salah satu karakter garis ekspresionis). Penggunaan garis membuat bangunan tidak monoton serta harmonis dengan alam sesuai dengan fungsinya(lihat pada Gambar 7).

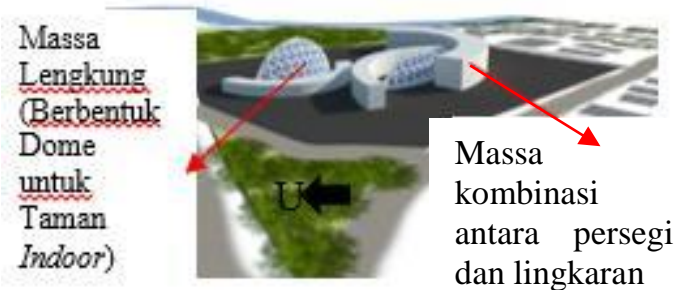

Gambar 7. Penerapan Arsitektur Ekspresionis pada Bentuk dan Massa

\subsection{Pengolahan Tampilan Bangunan}

Pengolahan tampilan bangunan dengan penerapan arsitektur ekspresionis akan dirancang sebagai berikut (lihat pada Gambar $8,9,10,11)$. 


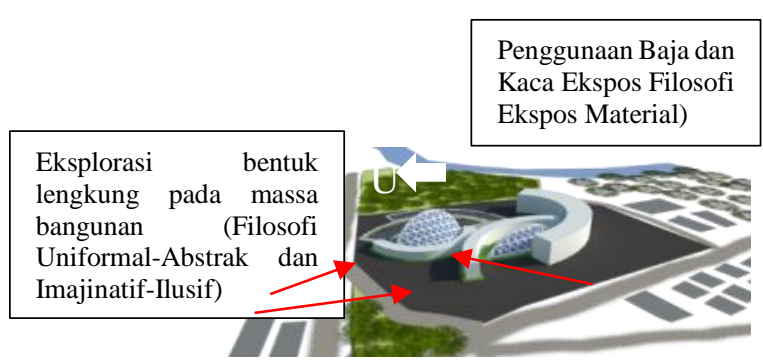

Gambar 8. Penerapan Arsitektur Ekspresionis pada Eksterior Bangunan

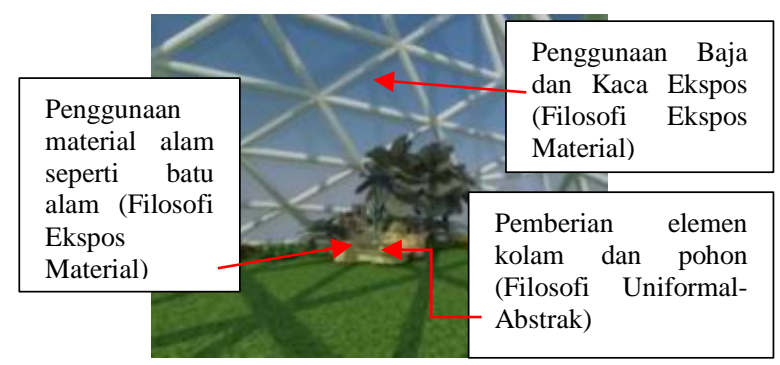

Gambar 9.Penerapan Arsitektur Ekspresionis pada Interior Bangunan

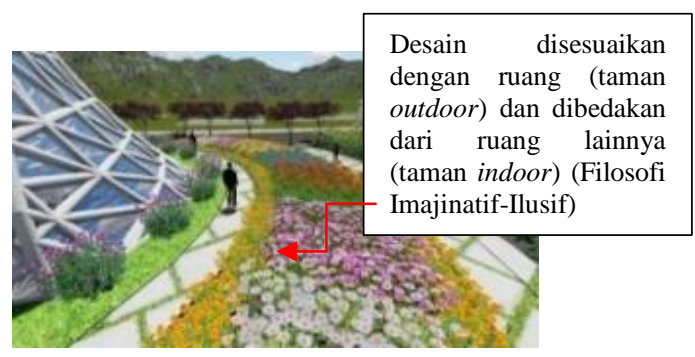

Gambar 10. Penerapan Arsitektur Ekspresionis pada Taman Bunga Outdoor

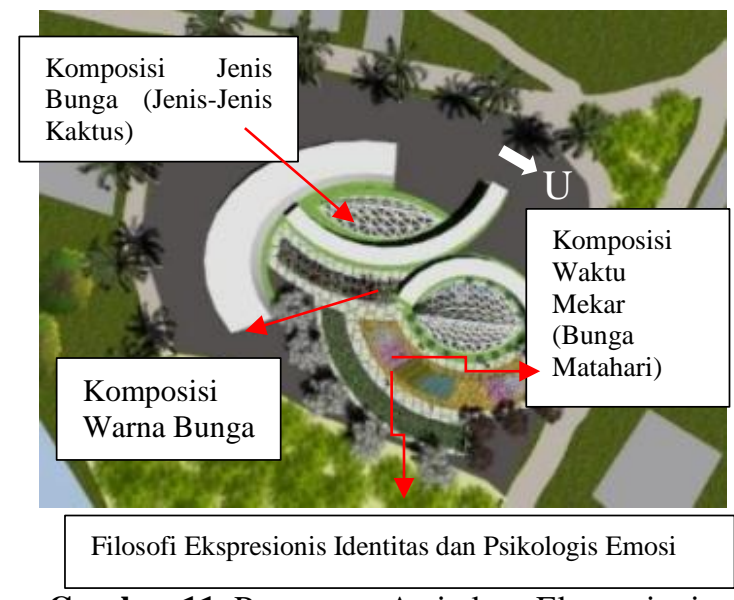

Gambar 11. Penerapan Arsitektur Ekspresionis pada Penataan Komposisi Bunga

\subsection{Pengolahan Struktur}

a. Material Struktur

1) Kaca

Penggunaan material kaca untuk menjadi penutup kerangka pada dome-dome yang ada di Taman Bunga dan bangunan lain.

2) Baja

Penggunaan material baja untuk menjadi mayoritas material konstruksi pada bangunan, baik dalam penggunaan konstruksi cangkang.

3) Kayu

Pada bagian lantai menggunakan lantai plesteran dan lantai parket untuk memberi kesan alami.

\section{b. Sistem Struktur \\ 1) Upper Structure}

Struktur upper structure yang akan digunakan pada perancangan Taman Bunga ini adalah:

a) Struktur Cangkang

b) Struktur Beton Bertulang

\section{2) Supper Structure}

Struktur supper structure yang akan digunakan pada perancangan Taman Bunga ini adalah:

a) Struktur Rangka dan Kolom Beton Bertulang

b) Struktur Shear Wall

\section{3) Sub Structure}

Struktur sub structure yang akan digunakan pada perancangan Taman Bunga ini adalah pondasi tiang pancang.

\subsection{Hasil Akhir Desain}

Hasil akhir desain Taman Bunga dengan Pendekatan Arsitektur Ekspresionis adalah sebagai berikut (lihat pada Gambar 12,13,14,15).

Nama Bangunan: Taman Bunga dengan Pendekatan Arsitektur Ekspresionis di Surakarta. 
Lokasi : Jl. Kyai H. Masykur, Jebres, Surakarta, Jawa Tengah 57126.

Luas Lahan $\quad: 50.300 \mathrm{~m}^{2}$

Luas Bangunan : $\pm 35.000 \mathrm{~m}^{2}$

Kegiatan :Rekreasi,

ekologis, edukasi dan ekonomi.

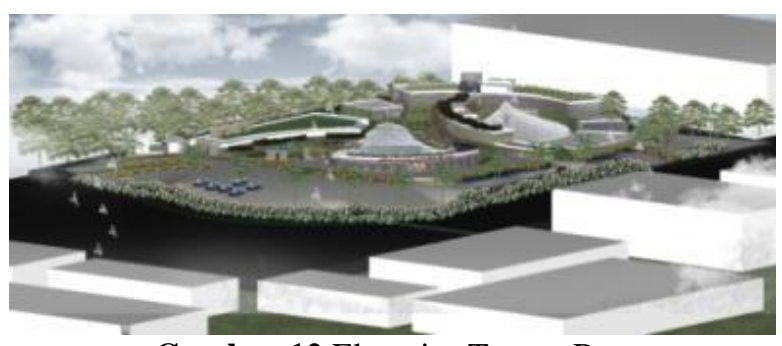

Gambar 12.Eksterior Taman Bunga

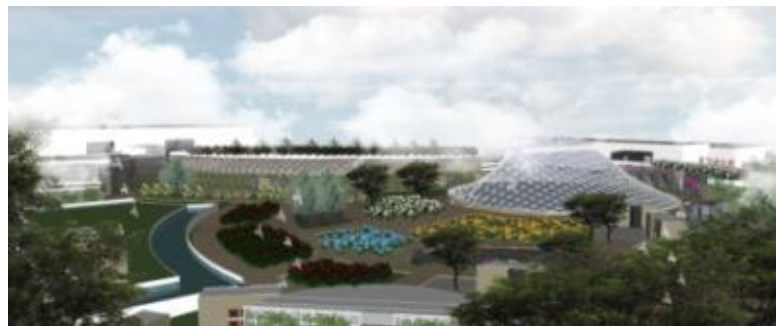

Gambar 13. Area Taman Outdoor

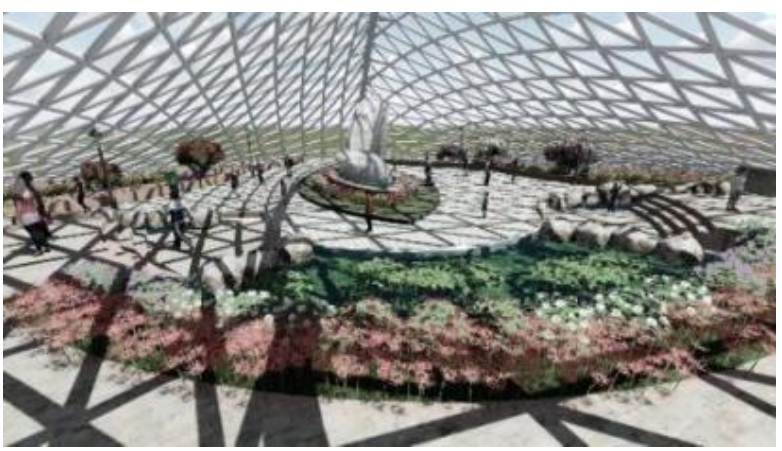

Gambar 14. Area Taman Indoor

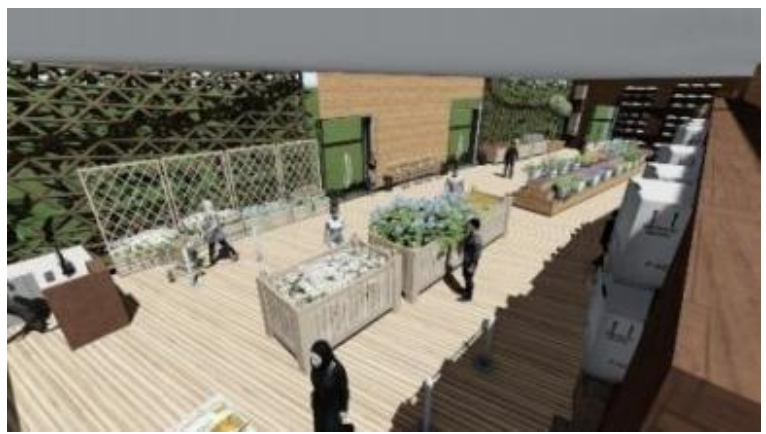

Gambar 15. Area Pasar Bunga

\section{KESIMPULAN}

Strategi desain yang diterapkan pada Taman Bunga ini adalah dengan merumuskan prinsipprinsip desain dengan mempelajari nilai, pedoman dan filosofi arsitektur ekspresionis yang nantinya dapat diterapkan pada desain bangunan.

Prinsip desain ini diterapkan pada pengolahan ruang yaitu bangunan dibuat majemuk sesuai fungsi (menggunakan makna dari simbol ide ruang). Penerapan pada pengolahan tapak dengan desain pencapaian, iklim, view dan orientasi, kebisingan dan polusi, dan zonasi menggunakan nilai arsitektur ekspresionis seperti kebebasan bentuk dan garis, mengungkapkan emosi lewat bentuk dan warna, penyampaikan emosi/rasa dari perancang.

Penerapan pada bentuk dan massa dengan kombinasi dan penerapan bentuk lengkung. Penerapan pada tampilan bangunan dengan menerapkan filosofi uniformal-abstrak, ekspos material, imajinatif-ilusif, identitas, psikologis emosi. Penerapan pada struktur bangunan dengan menggunakan material konstruktif.

\section{REFERENSI}

Fardaniwuri, Dhita. Suparno, \& Hari Yuliarso. (2016). GEDUNG PERTUNJUKAN MUSIK MODERN DENGAN PENDEKATAN ARSITEKTUR EKSPRESIONISME DI SURAKARTA. Arsitektura Universitas Sebelas Maret, 14.

Sudibyo, Brilly Prayudha. MDE Purnomo, \& Rachmadi Nugroho. (2016). GALERI MURAL DAN GRAFFITI DENGAN PENERAPAN KONSEP EKSPRESI DALAM ARSITEKTUR DI KOTA SURAKARTA. Arsitektura

Universitas Sebelas Maret, 14.

Van de Ven, Cornelis. (1991). Ruang Dalam Arsitektur (3rd ed.). Jakarta: Gramedia Pustaka Utama.

Peraturan Pemerintah Republik Indonesia Nomor 7 Tahun 1999 Tentang 
Pengawetan Jenis Tumbuhan dan Satwa.

Sp, Soedarso. (2000). Sejarah Perkembangan Seni Rupa Modern. Yogyakarta: Studio Delapan Puluh Enterprise bekerja sama dengan Badan Penerbit ISI Yogyakarta. 